\title{
Nervous Conditions on the Limpopo: Gendered Insecurities, Livelihoods, and Zimbabwean Migrants in Northern South Africa
}

\author{
BLAIR RUTHERFORD \\ Carleton University, Canada
}

\begin{abstract}
This paper examines some of the gendered insecurities informing some of the livelihood practices of Zimbabwean migrants in northern South Africa from 20042011, the period in which I carried out almost annual ethnographic research in this region. Situating these practices within wider policy shifts and changing migration patterns at the national and local scales, this paper shows the importance of attending to gendered dependencies and insecurities when analysing migrant livelihoods in southern Africa. These include those found within humanitarian organizations targeting Zimbabwean migrants in their programs and policies in the border area. These gendered insecurities, which are woven into the fabric of travel, work and accommodation for these migrant Zimbabwean women in northern South Africa, should be examined in struggles for social justice. By drawing on the lens of social critique to engender a wider sense of the social justice needs for Zimbabwean women migrants in South Africa, this essay aims to broaden the focus of activism on women migrants to also attend to gendered insecurities in their everyday economic and shelter-seeking activities.
\end{abstract}

KEYWORDS South Africa; Zimbabwe; gender; insecurities; migration

\section{Introduction}

It was already one of those awkward research moments where my expectations clashed with those who were introducing me to others, which then became much, much more uncomfortable. It was July 3, 2005 and I was spending my first full day on a commercial citrus farm in Tshipise in northern South Africa to see if it could be a place for me to do some research on Zimbabwean migrants, who comprised the majority of the farm labour force. As I have commonly done in my research on issues concerning farm workers 
in southern Africa, the day before I had introduced myself to the farm operator to seek his (or, more rarely, her) permission to talk to the workers. This Afrikaner senior farm manager was rather indifferent to my research, more worried about potential changing governmental plans for land restitution in South Africa than issues concerning his largely foreign workforce. As I have experienced before, he had then handed me over to one of his senior workers, who himself was Zimbabwean, whom he trusted would not say or show me anything which could embarrass the farm and who also would faithfully report back to him about what I did.

The following day, I met up with this Zimbabwean farm supervisor. He decided that the best way for me to be introduced and carry out some initial research was to take me to the part of the workers' compound where food was being served to the seasonal workers, who all were Zimbabwean, after the citrus picking work was done for the day. As dozens of clearly tired men and women were queuing up for a plastic bag of sadza (known more widely in South Africa as pap, a thick cornmeal porridge) and beans, the supervisor loudly informed those waiting in ChiShona that I am a university researcher from Canada who would like to speak to them about their experience in South Africa and about crossing the border from Zimbabwe.

When there was a pause in the distribution of the cooked food, I suggested that if any would like to discuss their experiences a bit more, we could talk more privately on the edge of the clearing. A line of about 10 Zimbabwean workers formed to meet with me on an individual basis, in a way that made me feel like I was dealing with customers or clients and not to learn about their often grim tales of survival in Zimbabwe and South Africa.

All was going well, as I was gaining some more insight into the travels, travails, and ambitions of these Zimbabwean men and women in terms of crossing the border and living and working in northern South Africa. But I was not prepared for the young woman from near the end of the queue who came to me and spoke so softly and hesitantly that I initially had trouble understanding her. She would start talking about how hard it was to cross the nearby Limpopo river, which forms the international boundary between South Africa and Zimbabwe, and how there were robbers, colloquially called maguma-guma, prowling on the Zimbabwean edge of the border preying on the border-jumpers, and then she would go very quiet and look away. Initially, I gently asked for some elaboration, but she would follow the same pattern of talking for a bit of time before trailing off into embarrassed silence. It finally dawned on me what she was referring to, that she was sexually attacked, and my heart sank. I asked her if I could try to help her to see any health professionals in the nearby town of Musina, but she declined, as she said she was afraid of being caught as an "illegal migrant" in that urban centre and deported. I urged her to try to find some help, but I also recognized that she had approached me for some assistance and found me sorely lacking. She then left, heading back to the overcrowded part of the 
workers' compound where seasonal workers stayed, and I awkwardly continued talking with other Zimbabweans for some time.

Hers was a troubling story in and of itself, but also, because sexual attacks were not yet publicly discussed as part of the risks of "jumping the border," her allusion to this violence was particularly shocking to me. Since my first research visit to northern South Africa the year before, I had already heard of "maguma-guma," the name for the typically Zimbabwean men who would meet would-be migrants in the Zimbabwean border city of Beitbridge or in villages or unpopulated areas hugging the northern bank of the Limpopo and offer them guidance across the river (for a fee); they also could end up robbing migrants jumping the border. By this research trip in 2005 one person had mentioned to me in passing that women migrants faced the risk of rape. But this was the first time I had heard, albeit indirectly, of the risk of sexual violence from these putative border guides by someone who had experienced it.

By a few years later, knowledge of such attacks and risks was much more widespread in various public forms. This was partly a function of the reported rapid increase in the number of Zimbabwean women and children crossing the border as the first decade of the twenty-first century moved on (Crush, Chikanda \& Tawodzera, 2015, p. 371), but it was due also to a growing number of organizations working to assist undocumented Zimbabweans in this region. During my almost annual research trips to the region until 2011, I increasingly heard many such accounts, often quite explicit, not only from victims but increasingly from people who worked for the growing number of organizations who focused on Zimbabwean migrants in this border-zone. News stories and NGO reports added to the attention this sexual violence began to receive. The incidence of such attacks seemed to increase, and the predominantly women victims of them had become an object of humanitarian intervention by some NGOs in the border region.

For example, Médecins Sans Frontières (MSF) set up an office in Musina in late 2007 in response to the tens of thousands of Zimbabweans crossing into South Africa, where they provided emergency health services to these initially undocumented migrants fleeing political violence or the crumbling economy at that time in their home country. Over the next six years in which they operated their office in the border region MSF also developed a focus on survivors of sexual violence through, for example, setting up a clinic in Musina for survivors of "Sexual and Gender Based Violence" in April 2009. As they reported,

More than $75 \%$ of clients seen by MSF in April were raped while crossing the border, and nearly $60 \%$ were raped by more than one perpetrator. Seventy percent of the time, rapes were perpetrated with an armed threat (gun, knife, etc.) and almost $50 \%$ of clients had injuries due to associated violence. (MSF, 2009, p. 14).

While such work often provided important and timely support to women (and some men) who otherwise would have had difficulty getting medical 
treatment, as undocumented migrants generally faced obstacles at South African health clinics and hospitals despite constitutional provisions saying otherwise (Crush \& Tawodzera 2014), such efforts also contributed to the sense that sexual violence is principally a risk from illegally crossing the border, making it a function of the illegality of the migrants and thus solely a criminal matter, one which implies that state authorities need to act while humanitarian organizations assist those who were attacked. Although those called maguma-guma definitely contributed strongly to the main form of gendered insecurity for border crossers, particularly for those who were new to the task of "jumping" the Limpopo, such a concentrated focus of efforts directed towards what most officials called "SGBV" (sexual and gender based violence) at the border obscures wider practices of gendered insecurities, including violence, which many Zimbabweans, particularly women, encountered in the first decade of this century while seeking livelihoods and shelter in northern South Africa. The humanitarian focus on individual survivors of sexual violence puts into the shadow a whole range of other gendered insecurities, built particularly into the social and power relations through which many sought to forge livelihoods and shelter.

As Doris Buss (2014) has pointed out, such concentrated attention on women survivors of such extraordinary violence can miss out both other forms of quotidian gendered insecurities and ways of seeking to mediate them. This is not a critique of such efforts by activists, humanitarians and others who seek to help the survivors and stop such forms of sexual violence. Rather, I provide an alternative perspective that aims to provide insight into the deeper gendered hierarchies woven into everyday life faced by many migrant women, which occur in the penumbra of the glare of such massmediated spotlights. Whereas the activism by humanitarian organizations and others brought some help and assistance to women who experienced sexual and gender-based violence, ${ }^{1}$ it occluded gendered insecurities woven into migrants' attempts to seek livelihoods and shelter. In this paper, I argue that these insecurities are part and parcel of the gendered dependency relations Zimbabwean women migrants need to work through - and with - as they pursue both livelihoods and shelter in northern South Africa. ${ }^{2}$

These gendered insecurities, which are woven into the fabric of travel, work and accommodation for these migrant Zimbabwean women in northern South Africa should, I suggest, be examined in struggles for social justice for undocumented migrants and refugees in South Africa. Although in South

\footnotetext{
${ }^{1}$ According to a contact with the MSF office in Musina, MSF also provided assistance to the smaller number of male survivors of sexual violence, though there was limited public discussion of these male victims and survivors.

${ }^{2}$ Of course, it is important to point out that many South African women face incredible gendered insecurities, particularly in the form of sexual violence directed towards women, girls and LGBTQ+ people. This paper only refers to the particular insecurities faced by migrant Zimbabwean women in northern South Africa, and not, say, migrant women coming from Somalia, Ethiopia, DRC, etc. There may be an overlap with the types of insecurities faced by women from these other migrant communities and South African women, but not necessarily.
} 
Africa's major urban centres social justice activists have conducted innovative struggles for rights for refugees and against xenophobia drawing on humanitarian logics as well as political activism (Robins, 2009), the activism tends to focus on legal and humanitarian issues rather than the economic and housing insecurities faced by undocumented migrants (see Shannon Morreira's (2010) research on the role of an activist group working with Zimbabweans in Cape Town in the first decade of this century). As Morreira (2016) insightfully shows, Zimbabweans seeking asylum in South Africa during this period had great troubles translating their claims into the narrow legal language and practice of "human rights violations;" a language and practice that were generally indifferent to the everyday power relations facing the undocumented Zimbabwean migrants she studied in Cape Town.

During my research period, there were no social justice activists working with Zimbabwean migrants in northern South Africa. Humanitarian organizations helped to put a spotlight on vulnerabilities of women migrants to SGBV in northern South Africa, but this overlooked the insecurities migrant women negotiate in the form of gendered dependency relations shaping access to economic livelihoods and accommodation. Didier Fassin has suggested such occlusions of quotidian gendered insecurities (Buss 2014) are part of the growing hegemony of "humanitarian reason" as organizations and social scientists draw strongly on the lexicon of moral sentiments rather than social critique in both examining and acting upon the wider social world: "[i]nequality is replaced by exclusion, domination is transformed into misfortune, injustice is articulated as suffering, violence is expressed in terms of trauma" (Fassin, 2012, p. 6).

While tracing some of these gendered work experiences for Zimbabwean women in northern South Africa in the latter part of the first decade of this century, I will also show how the increasing presence of humanitarian and development organizations in this region after 2007 became incorporated into gendered livelihood strategies for these migrants. An institutional focus on "international migrants" can have consequences for the gendered livelihood strategies of these very migrants. By tracing how some of these humanitarian organizations became involved in Zimbabwean migrants' precarious attempts to find work and accommodation, my aim is to suggest the importance of also drawing upon the lens of social critique, what Fassin (2008, p. 339) calls a "critical discourse" that tries to render "the complexity of issues and positions (which can be taken into account by social agents themselves)," to engender a better sense of the wider struggles for social justice in which these Zimbabwean women migrants in South Africa should be placed. This essay aims to broaden the focus of social activism concerning refugees and undocumented migrants in South Africa to also attend to gendered insecurities in their everyday economic and shelter-seeking activities. Although there have not been any mobilizations around this issue, I suggest there should be, as another way to "bring about social justice for migrants [is] by disrupting political order that denies them existence, voices, subjectivity, 
and rights" (Basok, 2010, p. 99). Such a move, I suggest, allows an analysis to move beyond simply a "humanitarian reason" to one seeking social justice.

After sketching out the broader political economy and immigration regimes shaping Zimbabwean migrants in northern South Africa from the 1990s to 2011, I will provide some examples from both the commercial farms and the town of Musina of how gendered insecurities are interlaced within particular forms of hierarchical social and power relations shaping livelihood options for Zimbabwean women and men. These examples highlight issues of inequality in terms of access to and control over important resources, and those which emerge from relations of dependency involved in livelihood practices.

\section{South African Immigration Policies Towards Zimbabweans, 1990s-2011}

When I began doing ethnographic research in northern South Africa in 2004, it was very difficult to find anyone self-identifying as a recent migrant from Zimbabwe. In contrast, in 2010 it was easy to meet Zimbabwean migrants who had arrived during or after 2000 residing in the northern South African border town of Musina and surrounding area. Self-identifying Zimbabweans were working in the stores, hawking items on the sidewalk, and being paid as domestic servants in the town and townships; labouring in the fields, orange packing sheds, and in the offices of the commercial farms; and staffing a number of the non-governmental organizations operating there.

The growing number of Zimbabweans entering South Africa is connected to post-2000 shifts in Zimbabwe that saw growing political persecutions and a politically-induced economic "meltdown" as the ZANU (PF) government sought to maintain its grip on power, which led to a massive exodus of Zimbabweans (Hammar, McGregor \& Landau, 2010). An estimated three million plus Zimbabweans left since 2000; more than a million are estimated to be living in South Africa (Crush et al., 2015, p. 366).

In their examination of survey data from 1997, 2005 and 2010, Crush et al. (2015) show that by 2005 there were some significant shifts in the characteristics of Zimbabwean migrants to South Africa. Compared to those who migrated in the $1990 \mathrm{~s}$, these post-2000 migrants tended to be younger, following family members who had preceded them, while they themselves were more likely acting as a network for other family members and friends to follow them into the country. Moreover, there was a growing "feminization" of migrants as more women were crossing south over the Limpopo, given the worsening economic possibilities in Zimbabwe and the deterioration of the various forms of social safety nets.

From 2006-2011, a number of national and international organizations and government departments established offices in Musina, given the dramatic increase in numbers of Zimbabweans crossing the border who often were in a quite vulnerable situation. Their mandate was to address or assist the growing 
number of Zimbabweans passing through or remaining in the Musina area, fleeing political persecution or limited economic opportunities and trying to find a place of potential personal and financial security, at least temporarily (see also Morreira, 2016).

Amongst others, the South African Red Cross, Lawyers for Human Rights, MSF, the International Organisation for Migration (IOM), and the United Nations High Commissioner for Refugees (UNHCR) all opened offices in this border town. They joined Save the Children (UK) which already had a small program in Musina directed towards "street children" for some years as well as the Musina Legal Advice Office, which had been in existence since the late 1980s. Both of these organizations also started to develop programs for Zimbabweans in northern South Africa in the 2000s. A number of faithbased organizations, from established churches like the Catholic Church to congregations built around born-again evangelical ministers, opened up shelters for the Zimbabweans. The Department of Home Affairs built new offices and the Department of Labour opened up an office in the town. They were joined by peripatetic national and international journalists, officials with international NGOs such as Human Rights Watch and Refugees International, and academics and graduate students from South African and international universities, all focusing on Zimbabweans in Musina and the surrounding area.

There also were a number of changes in the broader immigration policies and the positioning of Zimbabweans in South Africa at large. ${ }^{3}$ Over the last 20 years, Zimbabweans have become publicly marked as the most numerous migrant group in South Africa. They are marked in the sense that they are more likely than members of other nationalities to be subjected to discourses and practices in South Africa that view them as "outsiders" and "aliens" makwerekwere in the national vernacular (Muzondidya 2010; Rutherford, 2008). This xenophobic sentiment often characterizes Zimbabweans and other African "foreigners" as threatening employment possibilities, security of property and of the person, public health, rights to public housing, and sexual relationships, amongst other issues that become identified for public concern and occasional moral panics and violence, particularly in the large urban centres of South Africa (Worby, Hassim \& Kupe, 2008). Although such violence has not been prevalent in northern South Africa, such widelyknown and mass-mediated xenophobic violence and sentiments contributed to feelings of insecurity and otherness for many Zimbabwean migrants living there during my period of research.

There were growing numbers of Zimbabweans migrating to South Africa by 2005 as its own politics became more violent, ${ }^{4}$ and its social services and economic possibilities began to collapse for the majority of its population.

\footnotetext{
${ }^{3}$ For greater insight into South African immigration policies more broadly, see Crush (1998), Peberdy (2009), and Landau (2010).

${ }^{4}$ See, e.g., Hammar, Raftopoulos \& Jensen (2004), Sachikonye (2011), and Rutherford (2017).
} 
South Africa was the major destination and the number of Zimbabweans being deported from South Africa increased dramatically: 10,861 in 1993, 21, 643 in 1997, 55,753 in 2003, and 204,827 in 2007 (Crush et al., 2015, p. 374). Home Affairs officials recognized very few Zimbabwean asylum seekers as bona fide refugees, leading to growing criticisms by national and international human rights and lawyers associations as potentially legitimate refugees were being deported back to Zimbabwe (e.g., HRW, 2006; Kriger, 2010; Morreira, 2016).

In July 2008, the Department of Home Affairs opened a Refugee Reception Office (RRO) in Musina, allowing asylum-seekers to initiate the process for applying for refugee status to South Africa closer to the international border. The number of applicants arriving at the new Musina RRO soon outpaced the staffing capacities and applicants from Zimbabwe (and elsewhere) remained for days, sometimes weeks, waiting for their documents. Many observers and journalists began to raise public health and security concerns, particularly after South Africa declared a cholera emergency in the district in December 2008 (in part as Zimbabweans were fleeing a cholera outbreak in Harare), and faith-based organizations began to establish shelters in Musina's townships for those waiting to receive their documents. International and national media sources increasingly ran stories about the humanitarian catastrophe (Rutherford, 2011b).

On April 3, 2009, in the middle of national election campaigns in South Africa, the then Minister of Home Affairs declared that there would be a moratorium on the deportation of Zimbabweans, Zimbabweans would be able to get 30 day visas to South Africa for free; a de facto policy emerged that the asylum-seeker's permit became the route for (quasi-)regularization. In northern South Africa, any Zimbabweans detained by authorities for lack of proper permits to be in the country were typically brought to the RRO to receive an asylum-seeker's permit, regardless of whether they fit the criteria for seeking asylum. With that permit, they had freedom of movement and employment while they waited for the slow process of being evaluated to see if they were recognized as legitimate refugees. This became the political subjectivity used by Zimbabweans to seek permission to stay in South Africa (Rutherford, 2011a).

Then in September 2010 the "special dispensation" for Zimbabweans was rescinded and those Zimbabweans who were in the country on an asylumseeker's permit had a short period to regularize their stay in South Africa by applying for work, study or business permits. The ensuing "Zimbabwean documentation project" was haphazardly applied (Segattie, 2011, p. 56), regularizing some 255,000 Zimbabweans, and deportations of Zimbabweans resumed again on October 7, 2011. 


\section{Gendered Insecurities and the (Inter)dependencies of Work and Accommodation}

The livelihood strategies for these Zimbabwean migrants were often predicated on dependencies or interdependencies that can lead to conflict, exploitation, and other forms of vulnerabilities. These are particularly marked for women. In this section I examine some of the livelihood activities of Zimbabwean women migrants in Musina and the surrounding commercial farms, focusing in particular on various forms of dependencies and interdependencies on which they are predicated, and some of the gendered insecurities with which they are associated. Some of these are conventional ones associated with workplaces, particularly those between employer or manager and employees, but others are also associated with landlords and humanitarian organizations themselves. By examining them, one recognizes that humanitarian organizations tend to overlook some vulnerabilities, and may themselves be implicated in them.

The conceptual assumption here is that agency often appears through relations of dependency and subordination, providing particular forms of "capacity for action" (Mahmood, 2001, p. 210). These relations of dependency have long structured livelihoods, relations of solidarity, and polities in southern Africa (Ferguson, 2015), and often entail various vulnerabilities. These are particularly acute for women.

Being a Zimbabwean woman in Musina during my period of research was associated with certain forms of work: washing clothes and doing other domestic labour; buying and selling objects such as fruit, boiled eggs, pens, etc.; and working in retail shops, particularly stores owned by South Asian men in the business centre of Musina. For example, many Zimbabwean women in 2009 walked through the streets of the townships, looking for such piece jobs, whereas others would have regular customers, doing their laundry on certain days of the week. Trading was another economic activity many Zimbabwean women (and men) pursued. They would draw on linkages to other Zimbabweans to get some capital to buy fruit or eggs and then vend them on the streets. Others would sell for other Zimbabwean women who bought the goods for sale, for a nominal amount of money or even simply for food.

Sometimes the women were able to exploit interdependencies for their own gain. One woman I call Siphiwe explained in 2010 how she gained capital for her own business when she arrived in 2008. She said that shortly after arriving in Musina she was asked by two women staying at one of the women's shelters to buy undergarments for them in town as they had been robbed and raped when they jumped the border. She had used that money to buy a box of biscuits, which she then sold in town for a profit, giving her extra money after buying the undergarments. With that money, she bought a chicken to cook and used the maize meal rations, which she received from a church, to cook sadza and chicken to sell to Zimbabweans waiting in the 
queue at the RRO to apply for an asylum-seeker's permit. She was able to borrow the pots and plates from the shelters she was staying at to do the cooking and to serve the meal. After three weeks she had enough money to pay rent for a room and to buy an electric stove to keep her business going.

Such paths were rare and precarious. For instance, Siphiwe ended up entering into a relationship with a man who had initially helped her business, but then, she said, ended up stealing much of her money and physically abusing her. Her experience was not unusual.

My research gathered numerous accounts of Zimbabwean women in northern South Africa who were confronted with demands for sex by those who controlled important resources in the workplace, accommodation, and transportation. Although I did learn about some cases of violent rape, more commonly men in positions of authority placed demands on women to have sex with them.

On the Tshipise farm mentioned in the introduction, both female and male Zimbabwean workers told me about what they called the "scheme" which occurred there. "If you want a job picking oranges here," expressed one Zimbabwean young man to me in July 2005, "you fall under the manager's scheme. You have to pay." The currency, so to speak, depended on the gender of the job-seeker. Men had to pay in cash. Women had to pay by sleeping with the manager. Although Zimbabwean men on this farm were more ready than Zimbabwean women to talk to me about this "scheme," a few women did tell that they had to submit to the demands of the manager to get a job. "Life is too hard here in South Africa for us Zimbabweans," observed one woman in August 2005, "there are too many predators here. Wild animals in the bush when jumping the border and human ones on the farms..."

I came across similar "schemes" on other farms, albeit not called that way. The term "scheme" reflects the general sentiment about practices whereby senior workers, often black South African or black Zimbabwean men, would seek to "profit" from their gate-keeping role in terms of resources - such as a wage-paying job - by demanding sexual services from women job-seekers. In his research on a northern South African farm Lincoln Addison (2014) calls this the gendered "sexual economy." Demands for sex are just one form of structural violence laced through the raced and gendered economic and authority relations operating on the farms there (Bolt, 2015, 2016).

I heard similar accounts by young Zimbabwean women who worked as shopkeepers in what were colloquially called "Indian stores." There are a number of relatively cheap consumer good wholesale and retail stores in Musina, particularly off the main-road, owned and operated by South Asian men (either born in South Africa or Asia). Although many young women with whom I spoke saw these low-paying jobs as attractive, because they did not have to work outside in the heat or engage in physical activity and (for some) could try to steal some merchandise for resale after work, many also talked about risks of sexual assault by their proprietors or managers. I met a 
few young women who said they left jobs in "Indian shops" because bosses were sexually assaulting or harassing them.

There were also risks in seeking accommodation in Musina. Unless the Zimbabwean migrants already knew people with whom they could stay, they often ended up finding their own accommodation. Many ended up staying with others they met in mkhukhu, typically one-room shacks built haphazardly in the backyard of houses in Musina's townships. Renting out such shelters became one means of income-generation Musina residents used since the growing influx of Zimbabweans coming into the town.

Although such accommodations tended to be fraught with uncertainty for both landlords and tenants - over payments, conditions, concerns about theft, etc. - they sometimes also entailed gendered insecurity for some Zimbabwean women. This usually took the form of landlords who offered free or subsidized rent if women slept with them, but I also heard examples of other forms of gendered coercion. One Zimbabwean woman migrant reported that her landlady required Zimbabwean women renting from her also to sell chicken feet at her bar. As this woman reported,

Because we did not understand Venda very well, the landlady would talk to some Venda men that she was offering them beautiful Zimbabwean ladies from her house. In return she would then ask the men to buy her beer. This was being done without our knowledge; whilst we were selling the chicken feet these men would come to us to ask for sex.

For many Zimbabwean women who came to Musina on their own, the precariousness of their livelihoods often overlapped with uncertainty over their shelter. Sometimes the dependencies in one could help in the other; at other times, it could lead to gendered vulnerabilities. Let me give the example of a Zimbabwean woman I call Taurai, who travelled to South Africa as her husband had migrated to the country the year before but had stopped sending money back to help cover some of the expenses for her and their children.

After leaving her children with her in-laws, Taurai arrived in the Musina taxi ranks in April 2009. A Zimbabwean woman who she met there advised her to stay in town and not travel further as she had no asylum-seeking permit. The woman who advised Taurai was selling boiled eggs in the taxi ranks and offered to share her room in a mkhukhu. In Taurai's words, "she told me that she had only stayed at this place for five days.... She herself was under the care of another Zimbabwean woman who was renting the mkhukhu as she had no money to rent or pay for her own mkhukhu." As Taurai had money that she gained from selling a cow in Zimbabwe from her husband's herd, she then found another mkhukhu via another Zimbabwean woman she met in the queue waiting for her asylum-seeker's permit. A month later the woman who shared her $m k h u k h u$ left to work on the surrounding farms and the following month Taurai found a job working in a spaza shop (a small shack selling basic food and household items, commonly found in townships). 
She then gave up her $m k h u k h u$ as she was able to sleep in the shop for free and worked as a shopkeeper for two months. As she was paid less than half of her agreed-upon salary, by the second month she left the spaza shop and went to stay at one of the women's shelters operated by churches in the township. A South African woman then came by the shelter looking for a housekeeper and promised a small stipend and a free room, so Taurai moved into a $m k h u k h u$ in the backyard of her employer's house, sharing it with six other Zimbabwean women. The employment relationship quickly deteriorated, and the South African woman then told her that she was not going to pay her any form of salary and began charging her rent. When Taurai started to complain, the landlady replied, in Taurai's words, "go and look for a boyfriend so that I could get some money. Go to the truck stop in town to find a boyfriend." Rather than taking up this proposition Taurai said she found piece jobs washing clothes and cleaning houses in a township of Musina to pay the rent; a number of the other women staying at this place were engaged in sex work as their main source of income.

In short, the livelihood and accommodation possibilities open to, and forged by, these Zimbabwean migrant women in northern South Africa were defined through various forms of hierarchies, dependencies and interdependencies that were highly gendered. They were also laced through with various forms of gendered and sexual vulnerabilities. Whereas some of the growing number of humanitarian organizations focused on such vulnerabilities, as noted in Taurai's account they themselves also provided their own forms of gendered dependencies informing livelihood and accommodation possibilities for Zimbabwean migrants.

\section{Humanitarian Organizations and Gendered Livelihood Strategies}

Humanitarian organizations in northern South Africa helped Zimbabweans in many ways over my research period - providing healthcare, legal advice, trauma care, and food, amongst other important services and support. They also worked with and lobbied different policy-makers on their programs directed towards Zimbabweans. However, I will focus on how these organizations played a less obvious but still important role in the changing social and legal circumstances concerning Zimbabwean migrants. None of them were involved in any social injustices with Zimbabwean migrants (at least as I discovered), but seeing how they themselves were positioned by Zimbabwean women and men in their precarious searches for work and housing underscores how their "humanitarian reason" overlooked one of migrants' key insecurities.

As my research assistant and I spent time with the NGOs and churchorganized shelters working with Zimbabweans in Musina we slowly realized that the sites of these organizations were also important places for many of the Zimbabwean migrants over and above the specific services that were 
available to them. They offered health care, shelter and legal support, and were also incorporated into a key aim for many of the migrants: strategies to find work.

For example, in July 2008 I was sitting inside a small storage room that also served as the office attached to the "I Believe in Jesus" camp located in one of the townships. This camp was established in early 2008 by Zimbabwean and South African pastors to serve as the temporary shelter for the many dozens of Zimbabwean men waiting for their applications for asylum-seeker's permits to be processed. This July morning when I was talking with one of the Zimbabwean pastors who opened and operated the camp (with support from the UNHCR, MSF and South African Red Cross), a middle aged black South African man entered the room with one of the Zimbabwean men who worked at the camp as an "usher," the term used for the few men whose job was to "maintain order." The pastor excused himself and went to speak with the South African man. A few minutes later, the pastor sent the usher outside, who then returned with one of the Zimbabwean women who helped to cook the evening food for the camp residents. Shortly afterward the South African man left the camp with the Zimbabwean woman in his truck.

The pastor then told me that the South African was a commercial tomato farmer who had approached the pastor a few days earlier inquiring about finding a woman to be a domestic servant. The pastor then approached one of the Zimbabwean women cooks and after confirming she was willing to work for the farmer, he contacted the farmer who then came to collect his new employee. As this example shows, the NGOs and church groups in their spaces and activities provided locations for humanitarian support as well as for Zimbabweans to look for jobs. They did so in three ways.

Firstly, they became known as places where Zimbabweans congregated. A young Zimbabwean woman standing outside a shelter for migrant woman in Musina told me, "the shelter helps by providing a clean place to stay and some food at night, though it isn't always filling. But the best part is that it's a place to find a job as employers always come by here looking for workers." Although acting as a recruiting site for cheap labour was not part of the declared aims of the shelter, it was a typical example of how organizations whose mandate focused on international migrants (particularly from Zimbabwe) in this border-zone were also used for other purposes by some of the social actors with whom they interacted.

Once the asylum-seeker's permit became treated as a de facto work permit after March 2009, South Africans looking for employees would come by these places assisting Zimbabweans. Such searches were very gendered. By 2009 , employers looking for women workers tended to go by the women's shelter. This would include those looking for domestic servants as well as commercial farmers looking for pickers or women to work in citrus packsheds. Occasionally, other Zimbabwean migrants would come by looking to employ women to work as a street vendor for them, going to sell fruit or other 
type of food on the town's sidewalks. In contrast, employers looking for male workers tended to go by the I Believe in Jesus camp, the El Shaddai location (a born-again church which provided a free hot lunch to migrants), or to the Department of Home Affairs' RRO, outside of which many Zimbabweans congregated waiting to see if their permit would be issued or renewed. Employers looking for men to work in construction jobs, day labour jobs requiring physical strength (such as off-loading delivery trucks) as well as commercial farm jobs would drive by these sites. Even though by 2011 these organizations tended to also assist migrants from other African countries, particularly the DRC, Ethiopia and Somalia, it was predominantly Zimbabweans who used these locations as places of recruitment for jobs.

Zimbabwean migrants knew these sites as places employers frequented, and many often stood by these places during the day with the aim of finding work. Some would come to these sites hoping to find permanent jobs or, for many others, to find temporary jobs to get enough funds to travel further south into the bigger urban areas of South Africa. Some Zimbabweans whom we met at these places had left most of their money with relatives in Zimbabwe or had it stolen as they jumped the border and were attacked by maguma-guma. They desperately needed some funds to travel.

The position for many migrants was very precarious, as illustrated by an example of a 35 year-old woman I call Chido who had initially arrived in Musina in 2003. Chido had begun making money in South Africa by selling bananas on the sidewalk for a few months and then until 2007 she was a money changer, making decent profits as she changed Zimbabwean dollars into South African rand, US dollars, Botswana pula and vice versa. She then sunk 6300 Rand of her profits into buying 70 boxes of green soap to sell to Zimbabwe but was duped by a visiting Zimbabwean man who claimed that he would sell them for her and split the profits. He took the soap and she never received any money from him. Chido then moved to the Women's Shelter in 2008 as she could no longer afford the rent and she was no longer able to send much money or food back to her dependents in Zimbabwe. Shortly afterwards she returned to Zimbabwe and over the next two years she would return occasionally to Musina, staying two or so months at the women's shelter. As Chido noted in November 2011, she gets "recruited at this shelter for piece jobs of washing and cleaning... I am paid 50 Rand each time that I am recruited to do these jobs. You know, I cannot just sit in Zimbabwe. I have to do something as I have five children and my husband has since passed away."

The second way these organizations were entangled in migrants' jobseeking strategies was that people working for them became recruiters or gobetweens for Zimbabweans, as in the example with the pastor at the I Believe in Jesus shelter, who arranged to find a domestic servant for the South African farmer. In many of the organizations, there were individuals who occasionally sought to arrange employment opportunities for Zimbabwean migrants. They either acted as go-betweens for possible employers or offered 
their own employment opportunities. The latter was the case at one church that provided a free lunch. The main person behind the church was an Afrikaner man who also was a businessman. He would hire some Zimbabwean male migrants for various jobs.

Third, the various organizations were occasionally sources of employment themselves. Some of the NGOs hired Zimbabwean migrants to carry out projects. Both the IOM and the Musina Legal Advice Office, for example, hired Zimbabwean migrants to undertake research or monitoring for them on a contract basis. The church-run shelters often hired Zimbabweans to cook, clean and provide security.

In these examples, the humanitarian organizations become incorporated into many Zimbabweans' strategies and tactics for seeking shelter, for finding livelihood opportunities for themselves and, often, for generating resources to remit back to dependents in Zimbabwe and staying secure and safe. My research shows that most of the Zimbabwean migrants who spent some time in northern South Africa sought to forge relations, including hierarchical ones, with other Zimbabweans or South Africans in order to access shelter, food, income, or travel arrangements, or to remit goods and cash back to Zimbabwe. These relationships were often precarious, risky and often temporary, as conditions changed. Women, in particular, tended to find such relations of dependency and interdependency risky. Yet, female migrants often had to rely on these relations as they sought out livelihood activities in South Africa.

In all of these activities, a crucial logic was the involvement of dependency relations. The humanitarian organizations became entangled in, and occasionally helped to perpetuate, what James Ferguson (2013) has called "declarations of dependence." Many Zimbabwean migrants staying in or passing through Musina from 2008-2011 saw the various humanitarian organizations as not only sources of help and aid but also gendered sites to find possible livelihood practices, even if this was not explicitly part of their programming. Indeed, sometimes the programming obscures one from recognizing these other uses Zimbabwean migrants made of humanitarian organizations.

\section{Conclusion}

Borne out of uncertainties over their legal status, where and how they can find food to eat if not ways to earn money and a place to stay, and the reasons that led them to travel to South Africa (political violence, marital uncertainties, severe poverty, etc.), Zimbabwean migrants in northern South Africa were generally in precarious positions. The types of precarity shifted 
as the policies, laws and wider economies changed between 2004 and $2011 .^{5}$ But generally these types of precarity were amplified for many of these Zimbabwean women by the different forms of gendered violence and gendered insecurities they could encounter in seeking a way to make a living or some sort of shelter.

As Pamela Scully (2011, p. 30) has pointed out in her wider historical analysis of human rights initiatives directed towards African women, it "seems more difficult [than expected] to bring discussions of sexual violence within the field of economic and social justice." Shannon Morreira (2010, p. 446) argued that the activism by a social justice organization working with Zimbabwean asylum seekers in Cape Town in 2006 downplayed "conditions in which asylum seekers lived in communities in townships in South Africa." With the absence of social justice organizations working with Zimbabwean migrants in northern South Africa during my research period - and no identifiable social justice initiatives by these Zimbabweans themselves - I have examined the actions of humanitarian organizations. Whereas media and some humanitarian organizations brought much attention to the risks of sexual violence in terms of crossing the border, there was no public discussion of the quotidian gendered violence and insecurities Zimbabwean women faced in the workplaces, shelters, or other areas in which they were operating through relations of dependency. I encountered more women who worried and talked about the insecurities around forging a livelihood and findinga place to stay than who discussed the dangers coming from the maguma-guma. I am not saying it is an either/or situation - either one should focus on the sexual violence risk at the border or the gendered violence and insecurities embedded in many of the livelihoods - but without acknowledging the interrelationships of sexual violence with economic injustices, the humanitarian advocacy around refugees and undocumented migrants in South Africa misses out on an important source of gendered insecurity.

My title echoes the celebrated novel by Tsitsi Dangarembga. In Nervous Conditions Dangarembga eloquently and insightfully demonstrates the colonial, racist, patriarchal, and gerontocratic pressures and inequalities which shaped black women's bodies and lives in colonial Zimbabwe in the 1960 s and early 1970s during the intensification of the armed liberation struggle. Her subtle and critical portrayals include a limning of patrilineal and affinal hierarchies and the gendered dynamics and insecurities involved in them. Such a social layering shows that the subject position of being a woman has been shaped by "generations of threat and assault and neglect" (Dangarembga, 1988, p. 138). These various forms of dependency shaped by age, gender, and lineage dynamics of kin and affinal relationships all contribute to the nervous conditions of the female characters.

\footnotetext{
${ }^{5}$ Some Zimbabweans were far from vulnerable but profited in various ways from their time in South Africa.
} 
Analogously, highlighting the gendered dependency relations shaping strategies for livelihood and accommodation by Zimbabwean women migrants in northern South Africa troubles portrayals of Zimbabwean women migrants as mainly victims of trauma due to risks of SGBV. It disrupts (Basok, 2010) the focus on exceptional traumatic situations by humanitarian logics, by examining the vulnerabilities found in everyday inequalities that social justice perspectives can demonstrate. As the number of Zimbabweans crossing the border increased after 2000, there was growing humanitarian and policy attention to their situation in northern South Africa (and elsewhere in the country). In terms of women migrants, this attention was mainly directed towards women's shelters, health care, and attending to victims of sexual violence at the hands of maguma-guma. Such blatant attacks are arresting and disturbing, as I experienced in a passing way in 2005. Nonetheless, generally unremarked by many of these organizations was the threat of gendered insecurities within the livelihoods and strategies for shelter facing many Zimbabwean women living on the commercial farms in northern South Africa and in Musina. Through my "critical discourse" (Fassin, 2008, p. 339) trying to better render some of the positions and gendered power relations that many of these women had to address in northern South Africa, I have aimed to show the importance of mobilizing wider social justice initiatives rather than (only) focusing on humanitarianism (Morreira, 2016). Power and dependency relations in which many humanitarian organizations themselves became part and parcel, help to constitute the nervous conditions of the agency of these women.

\section{Acknowledgements}

I want to thank the Social Sciences and Humanities Research Council of Canada for generously funding this research and my good friend Rinse Nyamuda who assisted me with the research. I also want to warmly thank the two anonymous reviewers of my manuscript as well as my co-editors of this special issue, Daiva Stasiulis and Zaheera Jinnah for their very helpful comments on a draft of this paper, David Butz for his helpful editorial work as well as the audiences at the Studies in National and International Development seminar at Queen's University in 2013, the African Studies Association conference in 2014, the Carleton University 2016 symposium on "Intersectionality and Migration" for helpful feedback on my presentations of different aspects of this paper.

\section{References}

Addison, L. (2014). The sexual economy, gender relations and narratives of infant death on a tomato farm in northern South Africa. Journal of Agrarian Change, 14(1), 74-93. 
Basok, T. (2010). Opening a iadlogue on migrant (rights) activism. Studies in Social Justice, 4(2), 97-100.

Bolt, M. (2015). Zimbabwe's migrants and South Africa's border farms: The roots of impermanence. Cambridge: Cambridge University Press.

Bolt, M. (2016). Mediated paternalism and violent incorporation: Enforcing farm hierarchies on the Zimbabwean-South African border. Journal of Southern African Studies, 42(5), 911927.

Buss, D. (2014). Seeing sexual violence in conflict and post-conflict societies: The limits of visibility. In D. Buss, J. Lebert, B. Rutherford, D. Sharkey \& O. Aginam (Eds.), Sexual violence in conflict and post-conflict societies: International agendas and African contexts (pp. 3-27). New York \& London: Routledge.

Crush, J. (Ed.) (1998). Beyond control: Immigration and human rights in a democratic South Africa. Kingston, ON: Southern African Migration Project.

Crush, J., Chikanda, A., \& Tawodzera, G. (2015). The third wave: Mixed migration from Zimbabwe to South Africa. Canadian Journal of African Studies, 49(2), 363-382.

Crush, J. \& Tawodzera, G. (2014). Medical xenophobia and Zimbabwean migrant access to public health services in South Africa. Journal of Ethnic \& Migration Studies, 40(4), 655670 .

Dangarembgwa, T. (1988). Nervous conditions. Seattle, WA: Seal Press.

Fassin, D. (2008). Beyond good and evil?: Questioning the anthropological discomfort with morals. Anthropological Theory, 8(4), 333-344.

Fassin, D. (2012). Humanitarian reason: A moral history of the present. Berkeley, CA: University of California Press.

Ferguson, J. (2013). Declarations of dependence: Labour, personhood and welfare in southern Africa. Journal of the Royal Anthropological Institute, 19(2), 223-242.

Ferguson, J. (2015). Give a man a fish: Reflections on the new politics of distribution. Durham, NC: Duke University Press.

Hammar, A., Raftopoulos, B., \& Jensen, S. (Eds.) (2004). Zimbabwe's unfinished business. Rethinking land, state and nation in the context of crisis. Harare, ZI: Weaver Press.

Hammar, A., McGregor, J., \& Landau, L. (2010). Introduction. Displacing Zimbabwe: Crisis and construction in Southern Africa. Journal of Southern African Studies, 36(10), 263-283.

HRW (Human Rights Watch). (2006). Unprotected migrants: Zimbabweans in South Africa's Limpopo Province. Johannesburg, SA: HRW.

Kriger, N. (2010). The politics of legal status for Zimbabweans in South Africa. In J. McGregor \& R. Primorac (Eds.), Zimbabwe's new diaspora: Displacement and the cultural politics of survival (pp. 77-100). Oxford: Berghahn Books.

Landau, L. (2010). Loving the alien? Citizenship, law, and the future in South Africa's demonic society. African Affairs, 109(435), 213-230.

Mahmood, S. (2001). Feminist theory, embodiment, and the docile agent: Some reflections on the Egyptian Islamic revival. Cultural Anthropology, 16(2), 202-236.

Morreira, S. (2010). Seeking solidarity: Zimbabwean undocumented migrants in Cape Town, 2007. Journal of Southern African Studies, 36(2), 433-448.

Morreira, S. (2016). Rights after wrongs: Local knowledge and human rights in Zimbabwe. Stanford, CA: Stanford University Press.

MSF (Médecins Sans Frontières). 2009. No refuge, access denied: Medical and humanitarian needs of Zimbabweans in South Africa. Johannesburg, SA: Médecins Sans Frontières. http://www.msf.org/sites/msf.org/files/msf-no-refuge-access-denied.pdf

Muzondidya, J. (2010). Makwerekwere: migration, citizenship and identity among Zimbabweans in South Africa. In J. McGregor \& R. Primorac (Eds.), Zimbabwe's new diaspora: Displacement and the cultural politics of survival (pp. 32-58). Oxford: Berghahn Books.

Peberdy, S. (2009). Selecting immigrants: National identity and South Africa's immigration policies, 1910-2005. Johannesburg, SA: Wits University Press.

Robins, S. (2009). Humanitarian aid beyond "bare survival": Social movement responses to xenophobic violence in South Africa. American Ethnologist, 36(4), 637-650.

Rutherford, B. (2008). An unsettled belonging: Zimbabwean farm workers in Limpopo Province, South Africa. Journal of Contemporary African Studies, 26(4), 401-415. 
Rutherford, B. (2011a). Stabilizing boundaries: The shifting terrain of belonging for Zimbabweans in a South African border-zone. African Diaspora, 4(2), 207-229.

Rutherford, B. (2011b). The uneasy ties of working and belonging: The changing situation for undocumented Zimbabwean migrants in northern South Africa. Ethnic \& Racial Studies, 34(8), 1303-1319.

Rutherford, B. (2017). Farm labor struggles in Zimbabwe: The ground of politics. Bloomington, IN: Indiana University Press.

Sachikonye, L. (2011). When a state turns on its citizens: 60 years of institutionalised violence in Zimbabwe. Harare, ZI: Weaver Press.

Scully, P. (2011). Gender, history, and human rights. In D. Hodgson (Ed.), Gender and culture at the limit of rights (pp. 17-31). Philadelphia, PA: University of Pennsylvania Press.

Segatti, A. (2011). Reforming South African immigration policy in the postapartheid period (1990-2010). In A. Segatti \& L. Landau (Eds.), Contemporary migration to South Africa: A regional development issue (pp. 31-66). Washington, DC: The World Bank.

Worby, E., Hassim, S., \& Kupe, T. (Eds.) (2008). Go home or die here: Violence, xenophobia and the reinvention of difference in South Africa. Johannesburg, SA: Wits University Press. 